\title{
Effects of Jasmonic Acid, Ethylene, and Salicylic Acid Signaling on the Rhizosphere Bacterial Community of Arabidopsis thaliana
}

\author{
Rogier F. Doornbos, ${ }^{1}$ Bart P. J. Geraats, ${ }^{2}$ Eiko E. Kuramae, ${ }^{3}$ L. C. Van Loon, ${ }^{1}$ and Peter A. H. M. Bakker ${ }^{1}$ \\ ${ }^{1}$ Plant-Microbe Interactions, Institute of Environmental Biology, Utrecht University, Padualaan 8, $3584 \mathrm{CH}$ Utrecht, The \\ Netherlands; ${ }^{2}$ Seed Technology, Nunhems Netherlands B.V., Voort 6, 6083 AC, Nunhem, The Netherlands; ${ }^{3}$ Microbial Ecology, \\ Netherlands Institute of Ecology, Droevendaalsesteeg 10, 6708 PB Wageningen, The Netherlands
}

Submitted 19 May 2010. Accepted 9 December 2010.

Systemically induced resistance is a promising strategy to control plant diseases, as it affects numerous pathogens. However, since induced resistance reduces one or both growth and activity of plant pathogens, the indigenous microflora may also be affected by an enhanced defensive state of the plant. The aim of this study was to elucidate how much the bacterial rhizosphere microflora of Arabidopsis is affected by induced systemic resistance (ISR) or systemic acquired resistance (SAR). Therefore, the bacterial microflora of wild-type plants and plants affected in their defense signaling was compared. Additionally, ISR was induced by application of methyl jasmonate and SAR by treatment with salicylic acid or benzothiadiazole. As a comparative model, we also used wild type and ethylene-insensitive tobacco. Some of the Arabidopsis genotypes affected in defense signaling showed altered numbers of culturable bacteria in their rhizospheres; however, effects were dependent on soil type. Effects of plant genotype on rhizosphere bacterial community structure could not be related to plant defense because chemical activation of ISR or SAR had no significant effects on density and structure of the rhizosphere bacterial community. These findings support the notion that control of plant diseases by elicitation of systemic resistance will not significantly affect the resident soil bacterial microflora.

The bacterial rhizosphere microflora plays an important role in plant health. A well-studied phenomenon is the suppression of soilborne plant diseases by plant root-inhabiting bacteria, including members of genera Bacillus, Erwinia, Pseudomonas, Rhizobium, Serratia, and Xanthomonas (Weller 1988; Whipps 2001). Mechanisms of suppression of plant diseases by such bacteria include competition for substrates, competition for iron by siderophores, antibiosis, lytic activity, and induced systemic resistance (ISR) (Van Loon and Bakker 2003). Induced resistance is the state of enhanced defensive capacity developed by plants when appropriately stimulated (Van Loon et al. 1998; Van Wees et al. 2008; Zehnder et al. 2001). Rhizobacteria-mediated ISR is effective against a wide range of pathogens on dicotyledonous plant species, including Arabidopsis, bean, carnation, eucalyptus, radish, tobacco, and tomato (Bakker

Corresponding author: P. A. H. M Bakker; E-mail: p.a.h.m.bakker@uu.nl; Telephone: +31 (0)30-2536861; Fax +31 (0)30-2518366. et al. 2007), as well as the monocot rice (De Vleesschauwer et al. 2008). ISR resembles pathogen-induced systemic acquired resistance (SAR) in that i) upon challenge inoculation, induced plants show an enhanced defensive capacity, enabling the plant to respond faster, more effectively, or both to microbial attackers (Conrath et al. 2002, 2006; Van Wees et al. 2008) and ii) both are dependent on a functional NPRl gene (Pieterse and Van Loon 2004). However, whereas SAR is dependent upon the plant hormone salicylic acid (SA) and is associated with the expression of pathogenesis-related (PR) proteins, rhizobacteria-mediated ISR in Arabidopsis does not require SA signaling, nor is it associated with the expression of known defenserelated genes (Pieterse et al. 1996, 1998; Van der Ent et al. 2008; Van Wees et al. 1999; Verhagen et al. 2004). Instead, ISR requires responsiveness to jasmonic acid (JA) and ethylene (ET); yet, it is not associated with endogenous increases of these hormones (Pieterse et al. 2000).

In general, pathogens with a necrotrophic lifestyle are resisted by JA- and ET-dependent defenses, whereas SA-dependent defenses are effective against pathogens with a biotrophic lifestyle (Glazebrook 2005; Thomma et al. 1998). This differential effectiveness of plant defenses is also displayed by ISR and SAR (Ton et al. 2002). For example, ISR is effective against the necrotrophic fungus Alternaria brassicicola, whereas SAR is not; SAR is effective against the biotrophic Turnip crinkle virus, whereas ISR is not. However, almost nothing is known about effects of the augmented defensive state on the indigenous rhizosphere microflora. A recent study by Micallef and associates (2009) assessed the rhizobacterial community structure of eight Arabidopsis accessions. Of these, the non-ISR-expressing accessions RLD and WS-0 showed a bacterial community structure that tended to differ from that of the other six, which are ISR-inducible. Such differences might be related to differences in plant defensive capacity.

The aim of this study was to investigate whether the bacterial rhizosphere microflora is affected by one or both the JA/ETor SA-dependent defense-signaling pathways. Two experimental approaches were used. First, we analyzed the bacterial rhizosphere microflora of Arabidopsis thaliana accession Col-0 and derivatives affected in specific defense signal-transduction pathways. Second, we activated the JA- and SA-signaling pathways by exogenous application of the hormones, to study the effect of activated defenses on the bacterial abundance and community structure. 
In addition, we used tobacco and its ET-insensitive transformant, Tetr18 (Knoester et al. 1998; Wilkinson et al. 1997). Tetr18 plants have reduced resistance against several soilborne fungi and oomycetes, including species belonging to genera Fusarium, Thielaviopsis, and Pythium (Geraats et al. 2003; Knoester et al. 1998). Geraats (2003) suggested that Tetr18 plants differ from nontransformed plants in root characteristics that influence bacterial community structure in the rhizosphere. The Arabidopsis JA-response mutant jarl and ET-signaling mutant ein2 also have an enhanced susceptibility to different soilborne Pythium isolates (Geraats et al. 2002). Moreover, Arabidopsis genotypes affected in SA signaling display an enhanced sensitivity to the necrotrophic soilborne oomycete Phytophthora parasitica, the leaf spot fungus Cercospora nicotianae, and the hemibiotrophic bacterial leaf pathogen Pseudomonas syringae pv. tomato (Cao et al. 1994; Delaney et al. 1994). Conversely, the constitutive expressor of SA-dependent defenses cprl has increased resistance to the downey mildew oomycete Hyaloperonospora arabidopsidis as well as to $P$. syringae pv. maculicola (Bowling et al. 1994).

In order to obtain representative results, plants were grown on different soil types: i) a mixture of commercially available potting soil and sand and ii) a clay soil. Both soils were used as such or were autoclaved to allow possible species-specific recolonization from surviving bacteria or the ambient environment. The rhizosphere microflora, with focus on the total bacterial community and Pseudomonas spp., was explored using two complementary techniques, i.e., culturable-dependent semiselective plating was used for bacterial quantification and denaturing gradient-gel electrophoresis (DGGE), a culturable independent-fingerprinting technique, was used to monitor possible shifts in microbial community structure.
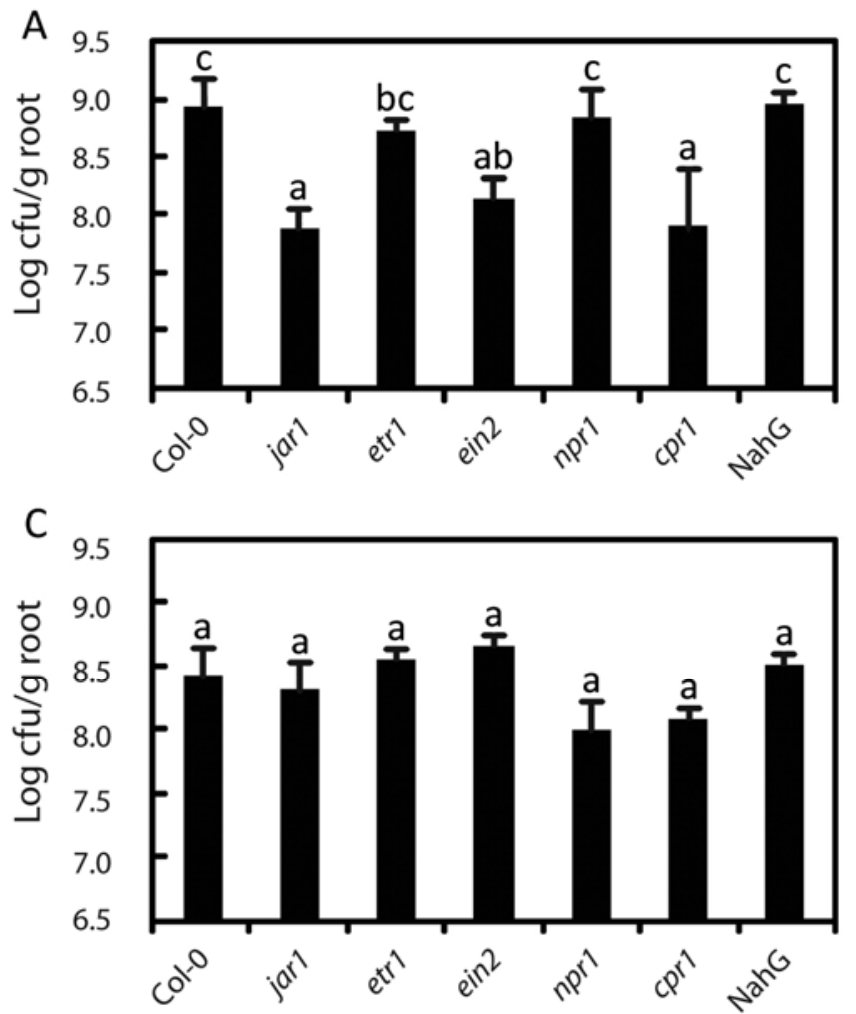

\section{RESULTS}

Abundance of rhizosphere populations of culturable bacteria and Pseudomonas spp.

The numbers of culturable bacteria and Pseudomonas spp. in the rhizospheres of Arabidopsis and tobacco plants were quantified by selective plating. To study a possible role of defense signaling, mutants affected in either the JA/ET or SA response were used. Power to detect differences between treatments was $100 \%$ for the total bacterial populations and $97 \%$ for numbers of pseudomonads in the nonautoclaved potting soil, as determined by power analysis. Population densities of total culturable bacteria in the rhizospheres of the different Arabidopsis genotypes grown on distinct soils ranged from $2 \times$ $10^{7}$ to $1 \times 10^{9}$ colony-forming units (CFU) per gram of rhizosphere soil (Fig. 1). Significant differences in bacterial numbers were only observed for plants grown in untreated potting soilsand mixture (Fig. 1A). The JA-response mutant jarl, the ETresponse mutant ein2, and the constitutive SA-producing cprl showed significantly lower numbers of culturable bacteria compared with the Col-0 wild type. These differences were not observed when the potting soil and sand mixture was autoclaved before use or when plants were grown on nonautoclaved or autoclaved clay soil (Fig. 1B through D). Numbers of CFU of Pseudomonas spp. in the rhizosphere were between $5 \times 10^{5}$ and $5 \times 10^{7}$ per gram of root and demonstrated tendencies similar to total bacterial numbers, except for ein2 (Fig. 2). However, Pseudomonas populations seemed more sensitive to SA-dependent defenses, as illustrated by a decreased abundance in cprl and a tendency of increased bacterial numbers in the NahG rhizospheres (Fig. 2A and B). Although differences in bacterial abundance between the geno-
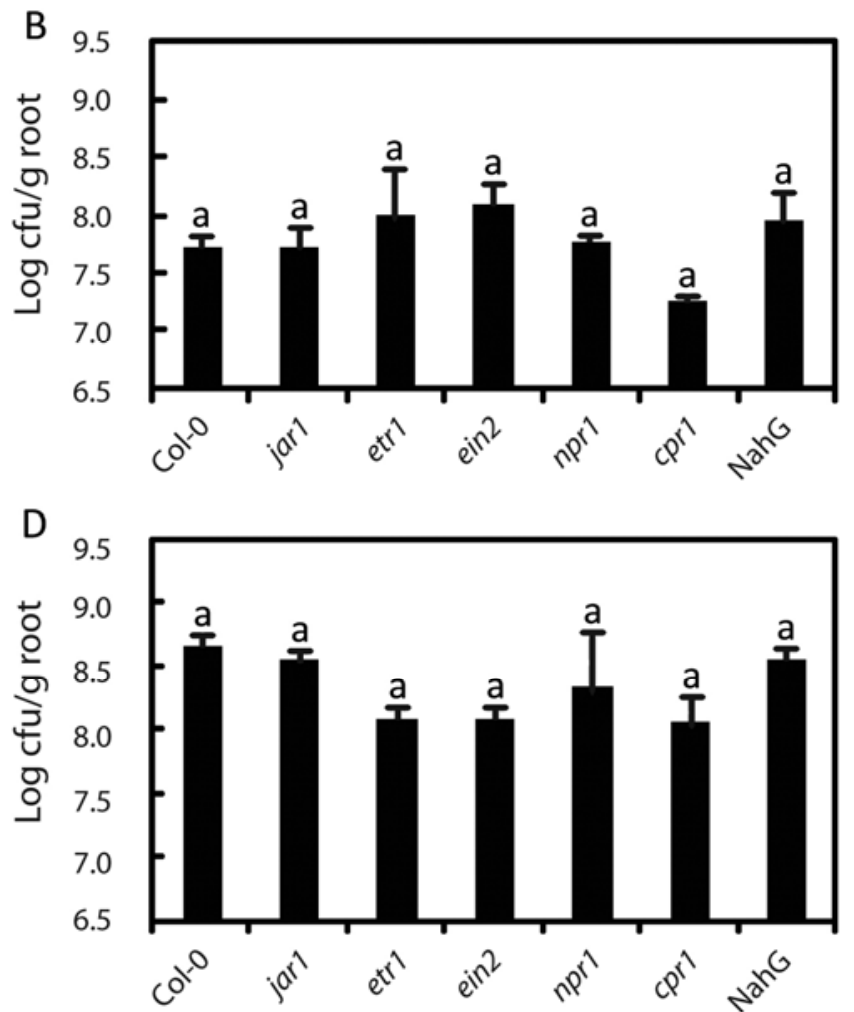

Fig. 1. Number of total culturable bacteria in the rhizosphere (log CFU per gram of root) of Arabidopsis Col-0 and Col-0 derivatives affected in jasmonic acid- (jarl and $n p r l)$, ethylene- (etrl, ein2 and nprl), or salicylic acid- (cprl, nprl and NahG) dependent defense responses. Rhizosphere samples of five individual plants were dilution plated on $1 / 10 \mathrm{TSA}^{+}(3 \mathrm{~g}$ of tryptic soy broth per liter, $13 \mathrm{~g}$ of agar technical per liter, and $100 \mathrm{mg}$ of natamycin per liter). A, Plants grown on potting soil-sand mixture. B, Plants grown on autoclaved potting soil-sand mixture. C, Plants grown on clay soil. D, Plants grown on autoclaved clay soil. Different letters indicate significant differences (analysis of variance and Tukey post-hoc test, $P<0.05$ ); error bars represent standard errors. 
types were not observed when plants were grown on the clay soil, Pseudomonas population densities were also consistently lower in the cprl rhizosphere (Fig. 2C and D).

The transgenic Tetr18 tobacco contains the mutant etrl ET receptor of Arabidopsis, resulting in ET insensitivity. When grown in either a potting soil-sand mixture or clay soil, autoclaved or not, no differences were observed in rhizosphere population densities of total culturable bacteria or Pseudomonas spp. (data not shown). These results are largely comparable to those of the Arabidopsis etr1 and ein2 genotypes.

\section{Composition of total bacterial \\ and Pseudomonas populations in the rhizosphere \\ of Arabidopsis defense signaling mutants.}

Possible differences in the bacterial rhizosphere community of the different Arabidopsis genotypes were studied in a culturable-independent manner, using polymerase chain reaction (PCR)-DGGE with eubacterial- and Pseudomonas spp.-specific primers. DGGE analysis revealed complex banding patterns containing 22 to 30 and nine to 18 distinct bands for plants grown on potting soil and clay soil, respectively. We used redundancy analysis (RDA) to evaluate effects of plant genotype on the rhizosphere microflora. Ordination plots of the eubacterial data are shown in Figure 3, and those for the Pseudomonas data are shown in Figure 4.

Analysis of similarity (ANOSIM) showed that the bacterial rhizosphere microflora was not significantly affected by plant genotype (Table 1). However, in all soils, the eubacterial rhizosphere microflora from mutants jarl, etrl, and ein 2 consistently clustered away from the Col-0 wild type. Similar results were obtained for the Pseudomonas spp. community. Independent of the soil used, the genotypes jarl, etrl, and ein2 clustered separately from the wild type, whereas the other genotypes showed more variable patterns in the different soils.

\section{Bacterial and Pseudomonas community structure}

in the rhizosphere of ET-insensitive tobacco.

The eubacterial and Pseudomonas rhizosphere communities of wild type and Tetr18 tobacco were not significantly different, as assessed by ANOSIM analysis of PCR-DGGE fingerprints (Table 2). Plants grown in nonautoclaved soil showed distinct clusters of the eubacterial microflora between the wild type and the Tetr18 transformant. This effect was less pronounced for the rhizosphere community of plants grown in autoclaved soil (Fig. 5). The rhizosphere Pseudomonas community only revealed separate clusters between wild type and Tetr18 tobacco for plants grown on a nonautoclaved potting soil and sand mixture (Fig. 6).

\section{Effects of foliar application of methyl jasmonate (MeJA), SA, and benzothiadiazole (BTH)}

on local and systemic VSP2 and PR-1 expression.

In the experiments with the defense-signaling mutants, no consistent differential effects of plant genotypes on rhizosphere bacterial communities were observed. Given that defense signaling was not elicited in these experiments, such an experimental outcome may not be surprising. To investigate if activetion of JA- and SA-signaling pathways affects the composition of the rhizosphere microflora, MeJA, SA, or BTH were applied to the leaves. Application of MeJA activated the JA-dependent defense response both locally (leaves) and systemically (roots), indicated by an about 7.5-fold increase in the expression of the JA-responsive marker gene VSP2 (Fig. 7A). Although SA and BTH application did not induce expression of VSP2 in the leaves, the ex-
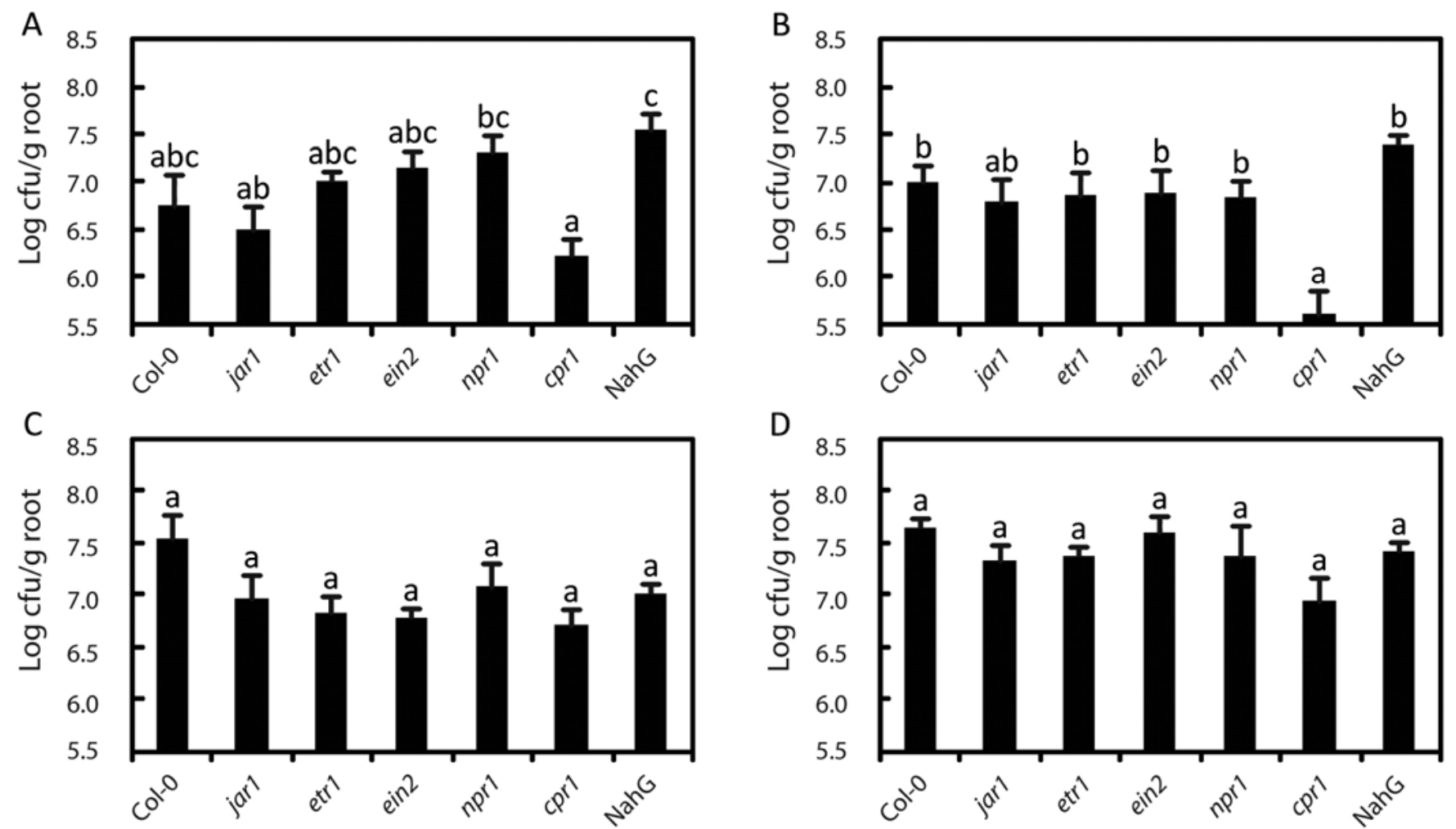

Fig. 2. Number of total culturable Pseudomonas spp. in the rhizosphere (log CFU per gram of root) of Arabidopsis Col-0 and Col-0 derivatives affected in jasmonic acid- (jarl and nprl), ethylene- (etrl, ein2 and nprl), or salicylic acid-dependent (cpr1, nprl and NahG) defense responses. Rhizosphere samples of five individual plants were dilution plated on $\mathrm{KB}^{+}$. A, Plants grown on potting soi-sand mixture. B, Plants grown on autoclaved potting soil-sand mixture. C, Plants grown on clay soil. D, Plants grown on autoclaved clay soil. Different letters indicate significant differences (analysis of variance and Tukey posthoc test, $P<0.05$ ); error bars represent standard errors. 
pression of VSP2 in the roots was increased 2.8- and 1.6-fold. Local expression of the SAR marker gene $P R-1$ was increased 49-fold in response to SA and 73-fold in response to BTH treatment (Fig. 7B). Foliar application of SA or BTH also resulted in activation of the corresponding defense-signaling pathway in the roots, as indicated by a nine- and fourfold induction of $P R-1$ expression, respecttively. As expected, application of MeJA did not affect $P R-1$ expression.

\section{Effect of activated defense signal-transduction pathways on bacterial abundance.}

The abundance of the bacterial and Pseudomonas spp. microflora in the rhizospheres of mock-, MeJA-, SA-, and BTHtreated plants was quantified by selective plating two weeks after treatment (Fig. 8). The numbers of CFU of total culturable bacteria in the rhizosphere of Col-0 revealed no significant influences of the hormone treatments. Likewise, activation of plant defenses had no effect on the numbers of total culturable bacteria in the rhizospheres of the mutants nprl and jarl nor in transgenic NahG plants. Colony counts of Pseudomonas spp. showed comparable results. However, compared with the mock-treated control, significantly higher numbers of Pseudomonas spp. were measured in NahG plants treated with SA or BTH.

\section{Effect of activated plant defense signaling on bacterial community structure.}

Ordination plots derived from DGGE fingerprints of the bacterial rhizosphere communities were generated by RDA and revealed that all samples clustered predominantly by plant genotype (Fig. 9). Induction of defense signaling in the different genotypes did not affect rhizobacterial communities, as the variables mock, MeJA, SA, and BTH are all in the center of the ordination plot. Pseudomonas-specific DGGE analysis revealed a higher variability among the samples, resulting in less
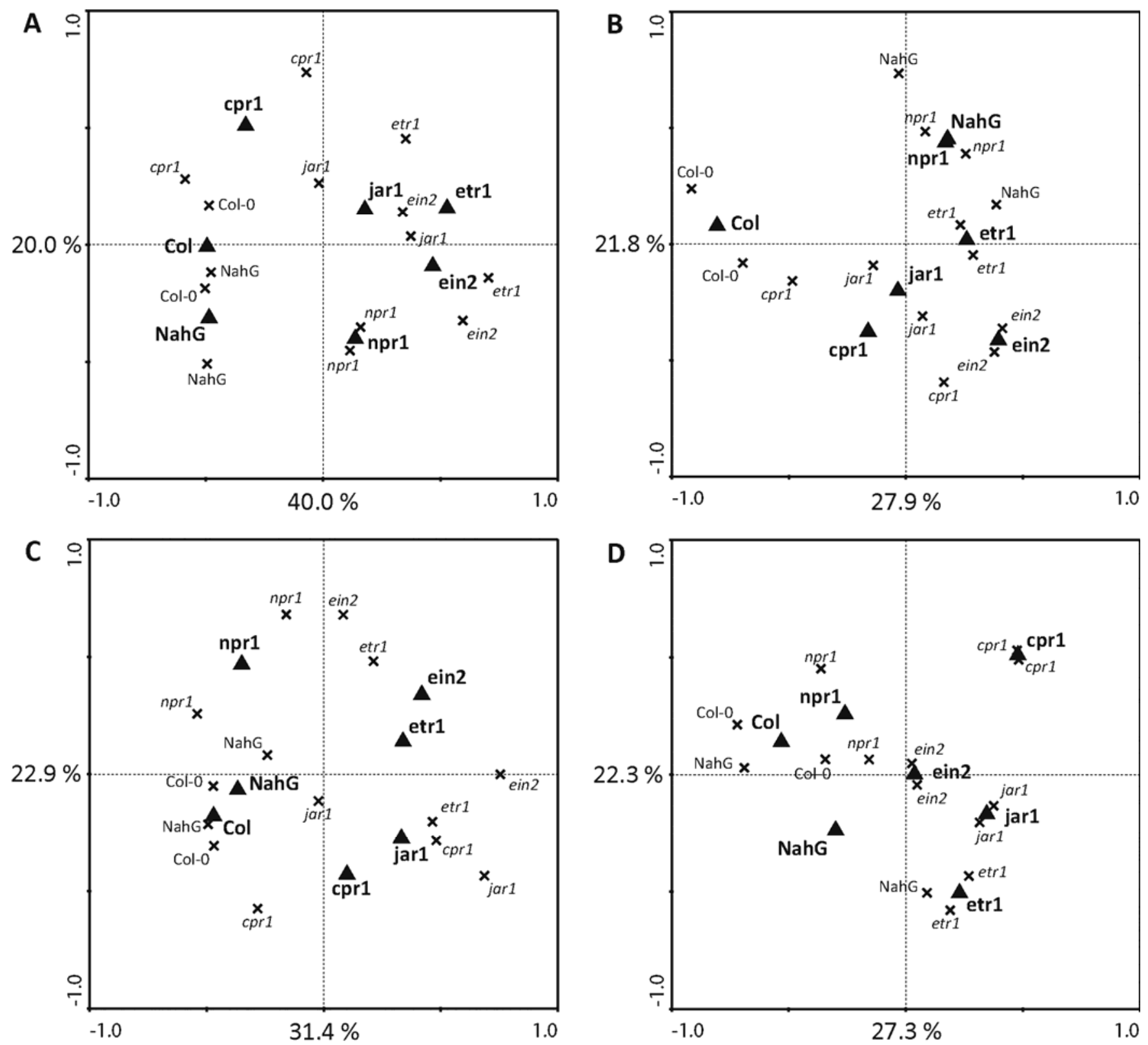

Fig. 3. Ordination biplots generated by redundancy analysis of eubacterial denaturing gradient-gel electrophoresis fingerprints of the rhizosphere of Arabidopsis Col-0 and Col-0 derivatives affected in jasmonic acid- (jarl and nprl), ethylene- (etrl, ein2 and nprl), or salicylic acid-defense (cprl, nprl and NahG) signal-transduction pathways. A, Plants grown on potting soil-sand mixture. B, Plants grown on autoclaved potting soil-sand mixture. C, Plants grown on clay soil. D, Plants grown on autoclaved clay soil. Crosses represent individual samples, triangles the centroid position of each genotype. 
distinct clusters compared with the eubacterial analysis. However, RDA analyses indicated that none of the hormone treatments had a relevant influence on the Pseudomonas community structure. Indeed, two-way ANOSIM analysis showed that eubacterial communities were significantly different with some overlapping ( $R=0.41924)$ in the rhizospheres of different Arabidopsis genotypes, while there were no significant effects of the hormone treatments (Table 3). For the Pseudomonas community, ANOSIM revealed significant differences in the rhizospheres of different Arabidopsis genotypes, but also, activation of defense signaling by applying hormones had no significant impact (Table 3 ) for this microbial group.

\section{DISCUSSION}

Rhizobacteria-mediated ISR and pathogen-induced SAR can reduce disease severity and microbial proliferation of a wide range of plant pathogens (Durrant and Dong 2004; Loake and Grant 2007; Van Loon 2007; Van Loon et al. 1998; Van Wees et al. 2008). However, it is not known if augmented plant-defense responses affect indigenous populations of plant-associated microorganisms. To elucidate if the bacterial rhizosphere microflora of Arabidopsis is affected by one or more JA-, ET-, or SA-dependent defenses, we investigated the abundance and community structure of the total bacterial microflora as well as the prevalent Pseudomonas spp. in the rhizosphere of different Arabidopsis and tobacco genotypes with altered defense signaling characteristics.

\section{Effect of plant defense signaling on bacterial abundances.}

Total bacterial and Pseudomonas spp. population densities in the rhizospheres of Arabidopsis and tobacco and of derivatives of these plants with altered defense signaling properties were studied by dilution plating on selective media. Bacterial
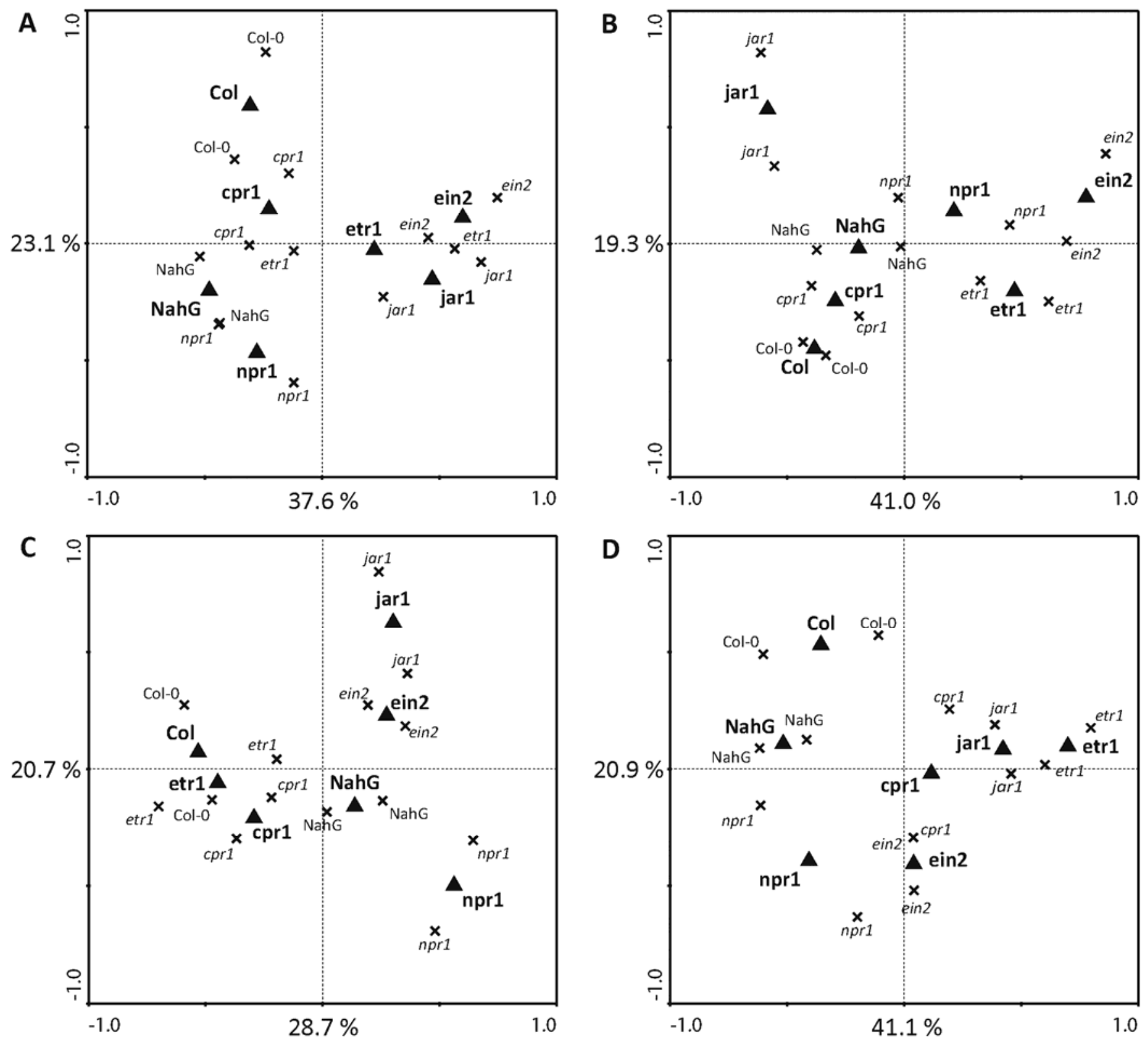

Fig. 4. Ordination biplots generated by redundancy analysis of Pseudomonas spp.-specific denaturing gradient-gel electrophoresis fingerprints of the rhizosphere Arabidopsis Col-0 and Col-0 derivatives affected in jasmonic acid- (jarl and nprl), ethylene- (etrl, ein2 and $n p r l)$, or salicylic acid-defense (cprl, nprl and NahG) signal-transduction pathways. A, Plants grown on potting soil-sand mixture. B, Plants grown on autoclaved potting soil-sand mixture. C, Plants grown on clay soil. D, Plants grown on autoclaved clay soil. Crosses represent individual samples, triangles the centroid position of each genotype. 
Table 1. One-way analysis of similarity of denaturing gradient-gel electrophoresis fingerprints of eubacteria and Pseudomonas spp. in the rhizospheres of Arabidopsis Col-0 and Col-0 derivatives affected in jasmonic acid- (jarl and nprl), ethylene- (etr1, ein2 and npr1), or salicylic acid(cprl, nprl, and NahG) defense signal-transduction pathways ${ }^{\mathrm{a}}$

\begin{tabular}{lcc}
\hline & \multicolumn{2}{c}{ Global R } \\
\cline { 2 - 3 } Soil & Eubacteria & Pseudomonas spp. \\
\hline Potting soil and sand & -0.1194 & 0.022 \\
Autoclaved potting soil and sand & 0.1188 & 0.1574 \\
Clay soil & -0.0600 & $0.3605^{\mathrm{b}}$ \\
Autoclaved clay soil & 0.02344 & -0.09375 \\
\hline${ }^{a}$ Plants were grown on potting soil and sand mixture, autoclaved potting \\
soil-sand mixture, clay soil, and autoclaved clay soil. \\
b $R$ values significant at $P<0.05$.
\end{tabular}
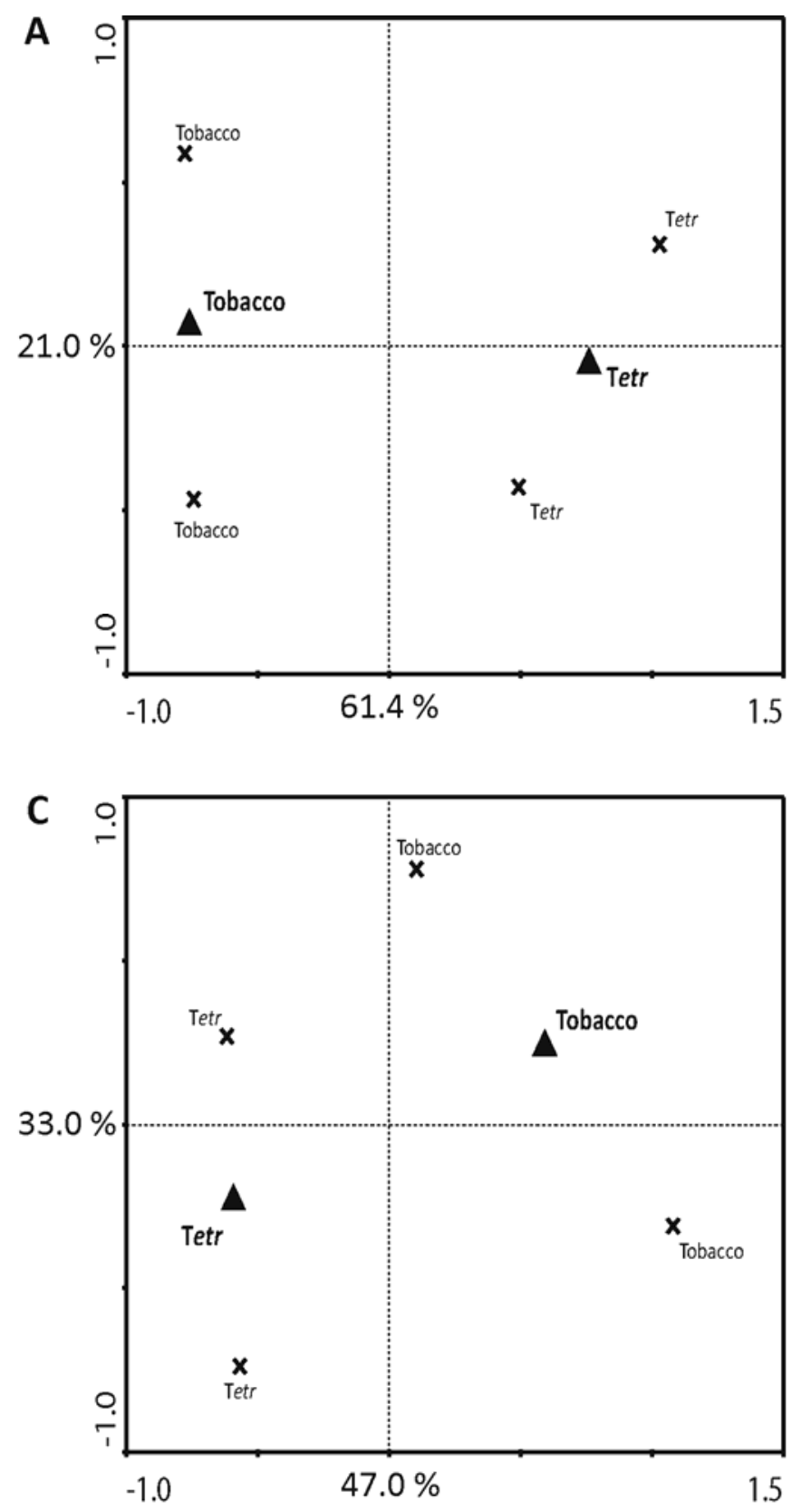

Table 2. One-way analysis of similarity of denaturing gradient-gel electrophoresis fingerprints of eubacteria and Pseudomonas spp. in the rhizosphere of tobacco wild type and its ethylene-insensitive transformant Tetr 18

\begin{tabular}{|c|c|c|}
\hline \multirow[b]{2}{*}{ Soil } & \multicolumn{2}{|r|}{ Global R } \\
\hline & Eubacteriab $^{b}$ & Pseudomonas spp. \\
\hline Potting soil and sand & 1.00 & 1.00 \\
\hline Autoclaved potting soil and sand & 0.25 & -0.12 \\
\hline Clay soil & 0.50 & -0.25 \\
\hline Autoclaved clay soil & -0.25 & -0.25 \\
\hline
\end{tabular}

a Plants were grown on potting soil and sand mixture, autoclaved potting soil-sand mixture, clay soil, and autoclaved clay soil.

${ }^{\mathrm{b}} R$ values not significant at $P<0.05$.

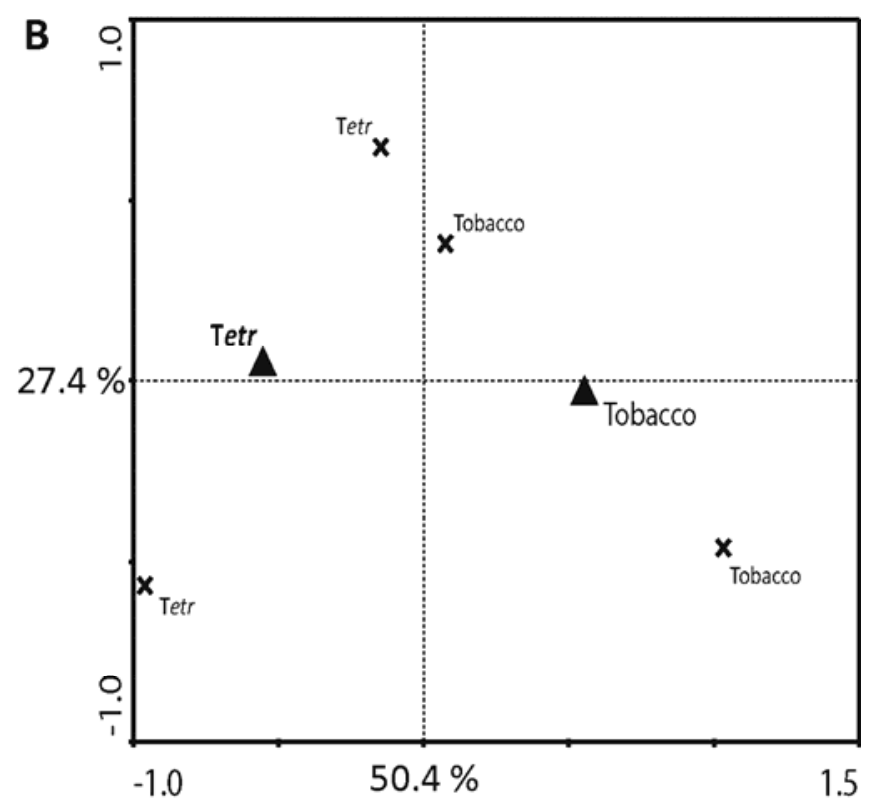

Fig. 5. Ordination biplots generated by principal component analysis of eubacterial denaturing gradient-gel electrophoresis fingerprints of the rhizosphere of tobacco wild type and its ethylene-insensitive transformant Tetr18. A, Plants grown on potting soil-sand mixture. B, Plants grown on autoclaved potting soilsand mixture. C, Plants grown on clay soil. D, Plants grown on autoclaved clay soil. Crosses represent individual samples, triangles the centroid position of the genotypes. 
population densities in the rhizospheres of the jarl and ein2 mutants were significantly lower compared with those in the wild-type rhizosphere when plants were grown in nonautoclaved potting soil-sand mixture (Fig. 1). However, such differences were not detected when plants were grown on clay soil or when the soil was autoclaved before use. Abundance of Pseudomonas spp. was not significantly different in the rhizospheres of JA- or ET-signaling mutants (Fig. 2). Likewise, rhizosphere population densities of total bacteria or Pseudomonas spp. of ET-insensitive Tetr18 tobacco were not different from those of wild-type tobacco (data not shown).

Soil type is one of the major factors determining bacterial community structure and activity in the rhizosphere (Berg and Smalla 2009; Garbeva et al. 2004a). Since differences in the bacterial abundances on the jarl and ein 2 roots were not detectable in the clay soils or when a new microflora was established after autoclaving, the decreased abundance is probably
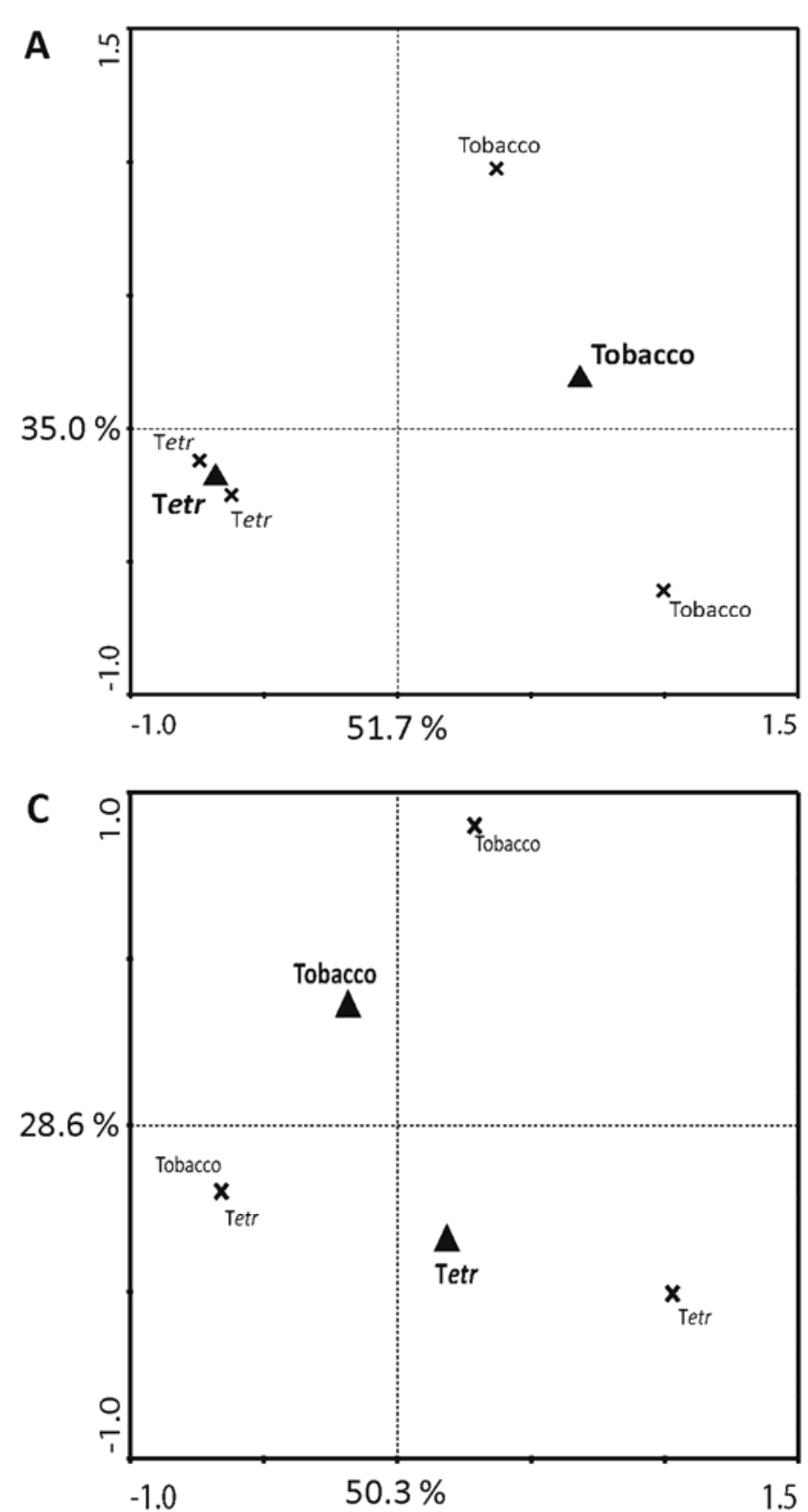

the result of the combination of plant genotype and other factors, such as extant microbial composition or edaphic variables. Indeed the eubacterial community structure of the nonautoclaved potting soil-sand mixture differs from that of the other soil types (Doornbos 2009). Marschner and associates (2001) experienced comparable bacterial community stability in a clay soil. Whereas their study found that root zone was an important factor for the composition of the rhizosphere communities in a sandy and a sandy loam soil, this was of little importance for the rhizosphere composition in the clay soil.

Since few differences were apparent in the absence of pathogens when defense signaling pathways are not activated, differences might only be expressed when plant defenses have been activated. Metabolic profiling of Arabidopsis roots upon chemical activation of plant defenses displayed secretion of numerous secondary metabolites, of which several have antibacterial and antifungal activity at the concentrations detected
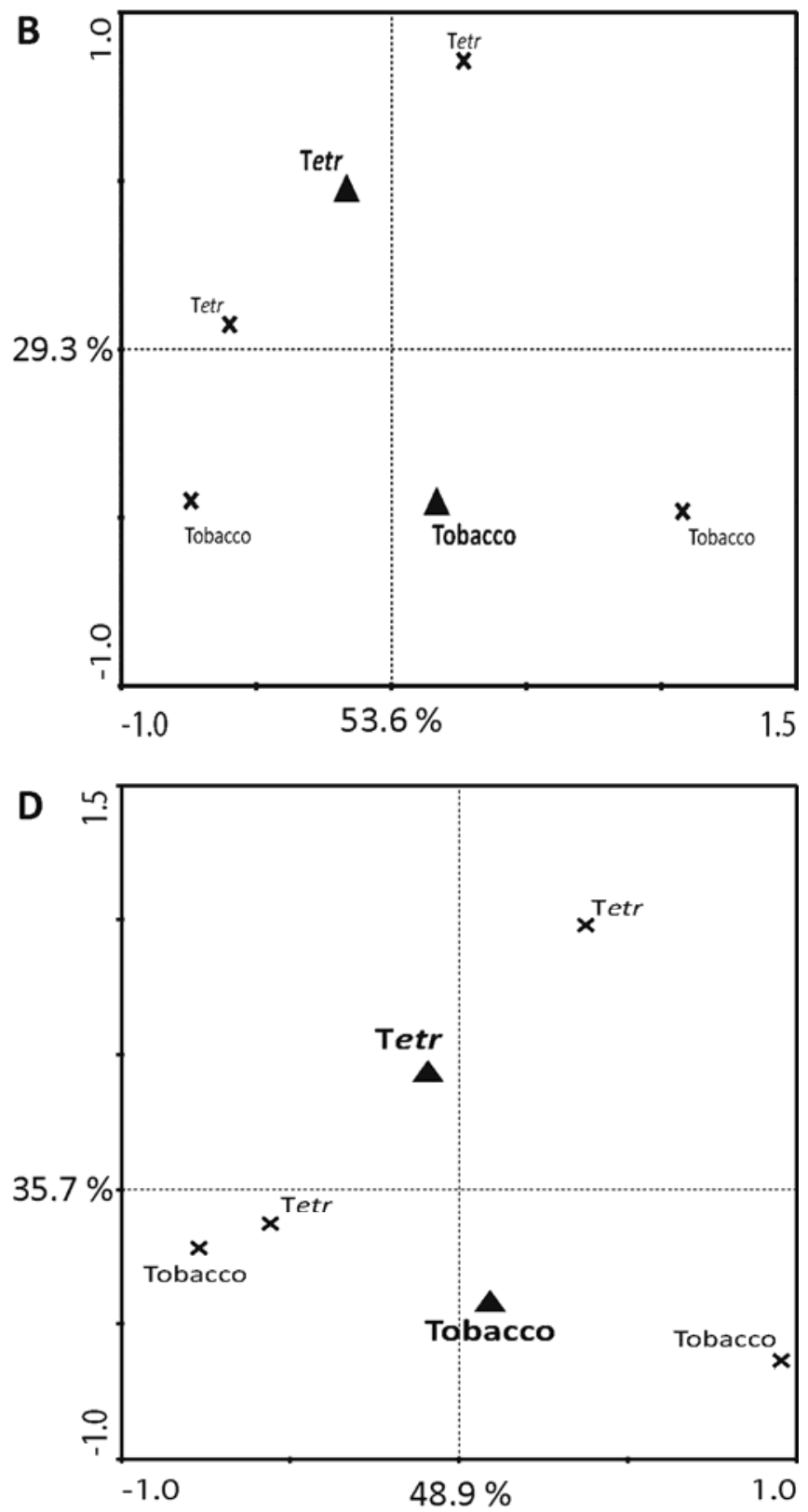

Fig. 6. Ordination biplots generated by principal component analysis of Pseudomonas spp.-specific denaturing gradient-gel electrophoresis fingerprints of the rhizosphere of tobacco wild type and its ethylene-insensitive transformant Tetr18. A, Plants grown on potting soil and sand mixture. B, Plants grown on autoclaved potting soil and sand mixture. C, Plants grown on clay soil. D, Plants grown on autoclaved clay soil. Crosses represent individual samples, triangles the centroid position of the genotypes. 
in the exudates (Walker et al. 2003b). For example, o-coumaric acid was secreted after JA treatment and has in vitro antimicrobial activity against Rhizoctonia solani, Erwinia carotovora, and Erwinia amylovora.

Activation of the JA-dependent signaling pathway by foliar application of MeJA resulted in local and systemic expression of the JA-responsive gene VSP2 (Fig. 7). However, VSP2 expression in roots was stimulated not only by JA but also, to a lesser extent, by SA and its functional analog BTH. In spite of the activation of the JA-dependent defense-signaling pathway, no significant changes in the abundance of total culturable bacteria or Pseudomonas spp. were apparent in the rhizospheres of Col-0, jarl, nprl, or NahG (Fig. 8). Thus, the induction of ISR does not influence the density of the Arabidopsis rhizosphere microflora.

In all soils used, we observed a consistently lower number of total bacteria and Pseudomonas spp. on the roots of the cprl mutant (Fig. 1 and 2). The cprl mutant contains a high level of SA, resulting in constitutive expression of SA-dependent defenses (Bowling et al. 1994). As a result, the cprl mutant has increased resistance to a variety of pathogens, including the oomycete Hyaloperonospora arabidopsidis and the bacterium $P$. syringae pv. maculicola (Bowling et al. 1994). This expression of defenses has energy costs involved (Heidel et al. 2004; Van Hulten et al. 2006; Walters and Heil 2007), resulting in a dwarf phenotype of the cprl mutant. To dissect the effect of activated SA signaling from the effect on plant growth, SAdependent defenses were activated in wild-type plants by foliar application of SA or BTH, as reflected by local and systemic expression of the SAR marker gene PR-1 (Fig. 7). Under these conditions, the activated SA-dependent defenses did not result

\section{A}
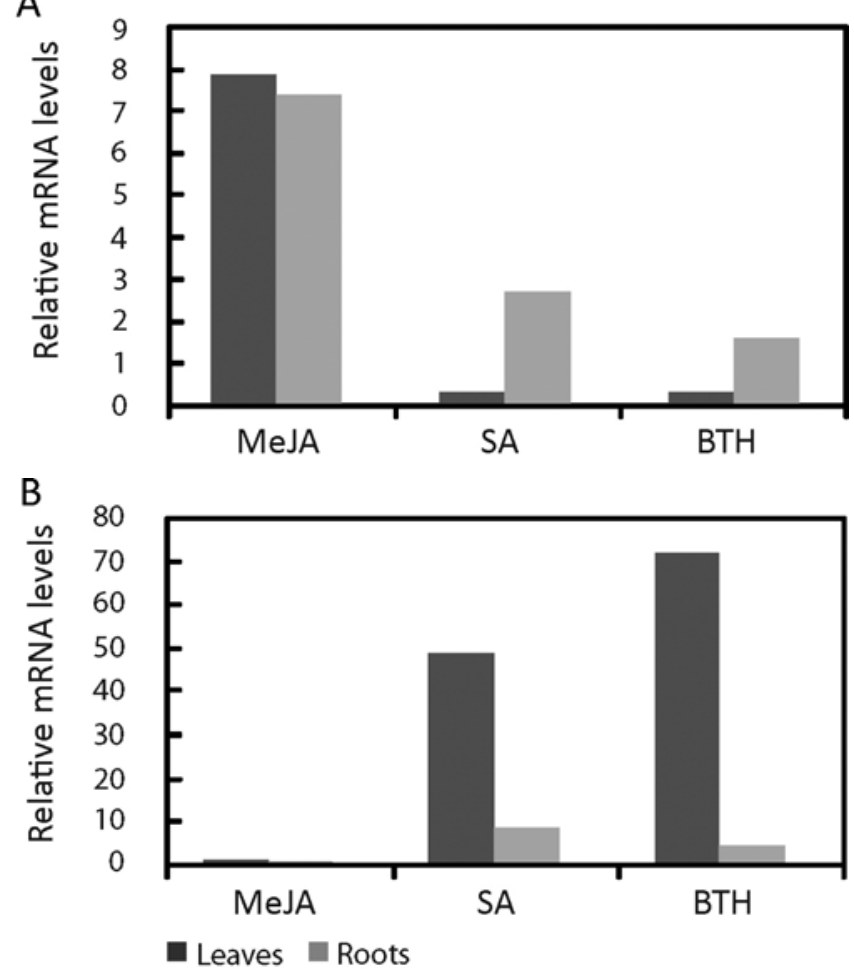

Fig. 7. Expression levels of $\mathbf{A}$, the jasmonate-responsive gene VSP2 and $\mathbf{B}$, the salicylic acid-responsive gene $P R-1$ in Arabidopsis Col-0 leaves (local effect) and roots (systemic effect) $24 \mathrm{~h}$ after foliar application of $0.1 \mathrm{mM}$ methyl jasmonate, $1 \mathrm{mM}$ salicylic acid, or benzothiadiazole $(200 \mu \mathrm{g}$ per milliliter) compared with mock-treated control (set at 1). Plants grown on nontreated potting soil-sand mixture. Cycle threshold change compared with mock-treated controls was as follows. VSP $2_{\text {leaves }}: 1.83, V S P 2_{\text {roots }}$ : $4.45, P R-1_{\text {leaves }}: 0.88$, and $P R-1_{\text {roots }}: 6.6$. in changes in the abundance of total culturable bacteria or Pseudomonas spp. in the rhizospheres of Col-0, nprl, or jarl (Fig. 8A through C). However, numbers of Pseudomonas spp. were increased in the rhizosphere of NahG (Fig. 8D). Because the NahG gene encodes salicylate hydroxylase, these plants convert SA to catechol (Delaney et al. 1994; Van Wees and Glazebrook 2003). In bacteria, $N a h G$ is part of the operon responsible for degradation of naphthalene, by which many pseudomonads can use aromatics as a carbon source (Yen and Serdar 1988; Zhao et al. 2005). It is possible and perhaps even likely that increased population densities of Pseudomonas spp. in the rhizosphere of SA-treated NahG plants result from increased levels of catechol in the rhizosphere. Also, BTH treatment may have increased SA content and, consequently, catechol levels in NahG plants. In strawberry, BTH treatment has been reported to increase SA content (Hukkanen et al. 2007); however, this does not occur in tobacco (Friedrich et al. 1996). In Arabidopsis, levels of phenolic metabolites are significantly reduced in BTH-treated plants (Hien Dao et al. 2009), but specific data for SA are lacking.

\section{Effect of plant defense signaling}

on the bacterial community structure.

Whereas effects of activated defense signaling on bacterial abundances were very small, these might still have affected bacterial diversity. Analysis of community structure of total bacteria and Pseudomonas spp. by PCR-DGGE and multivariate analysis demonstrated consistent clustering of the JA and ET mutants jarl, etr1, and ein 2 opposite to the Col-0 wild type (Figs. 3 and 4). In nonautoclaved potting soil and sand mixture the community structures of total bacteria and Pseudomonas spp. in the rhizospheres of NahG and jarl differed significantly from those of Col-0, as determined by ANOSIM analysis of the DGGE fingerprints (Fig. 9; Table 3). Thus plant genotype does affect bacterial communities, but the effects are not consistent and there is no apparent relation to plant defense signaling.

In ET-insensitive Tetr18 tobacco, Geraats (2003) observed that differences in the community structure of root-associated bacterial populations between wild type and the transformant were already detectable before spontaneous development of disease symptoms occurred. These symptoms occurred only when plants were grown in nonautoclaved soil; autoclaving the soil effectively reduced the population of deleterious oomycetes (Pythium spp.) held responsible for the wilting and root rot observed (Geraats et al. 2003; Knoester et al. 1998). In line with those results, we observed a more distinct difference of both eubacterial- and Pseudomonas spp. rhizosphere communities between Tetr18 and wild-type tobacco on nonautoclaved soils than on the soils that were autoclaved before use (Figs. 5 and 6). Although disease symptoms were not observed in our experiments, the shifts in the bacterial community structure may have been due to early stages of root infection causing changes in root exudates of the Tetr18 plants.

Activation of SA-dependent defenses did not alter total bacterial or Pseudomonas spp. community structure in the rhizosphere of Arabidopsis wild-type plants (Fig. 9). Whereas we observed reduced bacterial abundance in the rhizosphere of the cprl mutant, a reduction of the bacterial diversity in the cprl rhizosphere was not apparent. This observation is in line with observations made by Hein and associates (2008), who could not demonstrate a postulated decrease of bacterial diversity in the cprl rhizosphere by terminal restriction fragment length polymorphism. The cprl mutant has constitutively activated SA-dependent defense responses. Thus, it must be concluded that SA-activated SAR had no significant effect on bacterial and Pseudomonas rhizosphere community structures in the rhizosphere of Arabidopsis. 
Taken together, mutant and transgenic derivatives of Arabidopsis affected in ISR or SAR expression did have altered bacterial or Pseudomonas spp. population densities in their rhizosphere, but no consistent impact on community structure of rhizosphere bacteria was apparent. Moreover, activating the JA or SA defense-signaling pathway by exogenous application of MeJA, SA, or BTH had no effect on the bacterial rhizosphere microflora, either. In tobacco, differences in the bacterial community structure were observed between wild type and ETinsensitive Tetr18 plants, but only when these plans were grown
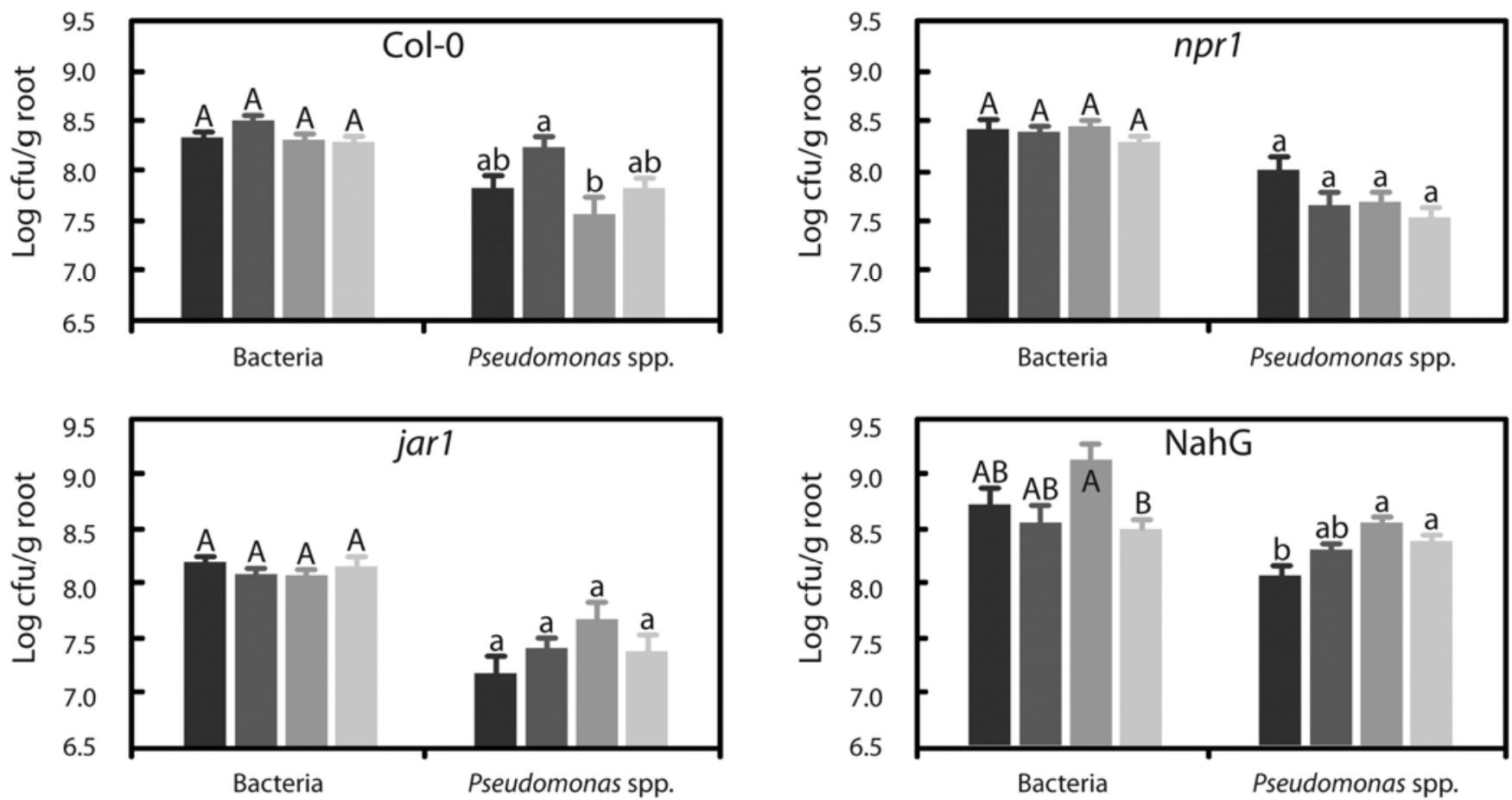

Mock $\square$ MeJA $\square$ SA $=\mathrm{BTH}$

Fig. 8. Numbers (log CFU per gram) of total culturable bacteria and Pseudomonas spp. in the rhizosphere of Arabidopsis Col-0 and its derivatives affected in defense signaling 2 weeks after foliar treatment with $0.1 \mathrm{mM}$ methyl-jasmonate, $1 \mathrm{mM}$ salicylic acid, or benzothiadiazole (200 $\mu \mathrm{g}$ per milliliter). Plants were grown on a potting soil-sand mixture. Rhizosphere samples of five individual plants were dilution plated on ${ }^{1 / 10} \mathrm{TSA}^{+}(3 \mathrm{~g}$ of tryptic soy broth per liter, $13 \mathrm{~g}$ of agar technical per liter, and $100 \mathrm{mg}$ of natamycin per liter) and $\mathrm{KB}^{+}$(King's B agar supplemented with $13 \mu \mathrm{g}$ of chloramphenicol per milliliter, $40 \mu \mathrm{g}$ of ampicillin per milliliter, and $100 \mu \mathrm{g}$ of natamycin per milliliter). Different letters indicate significant differences (analysis of variance and Tukey post-hoc test; $P<0.05$ ), capitals and lower-case letters indicate a separate comparison; error bars represent standard errors.
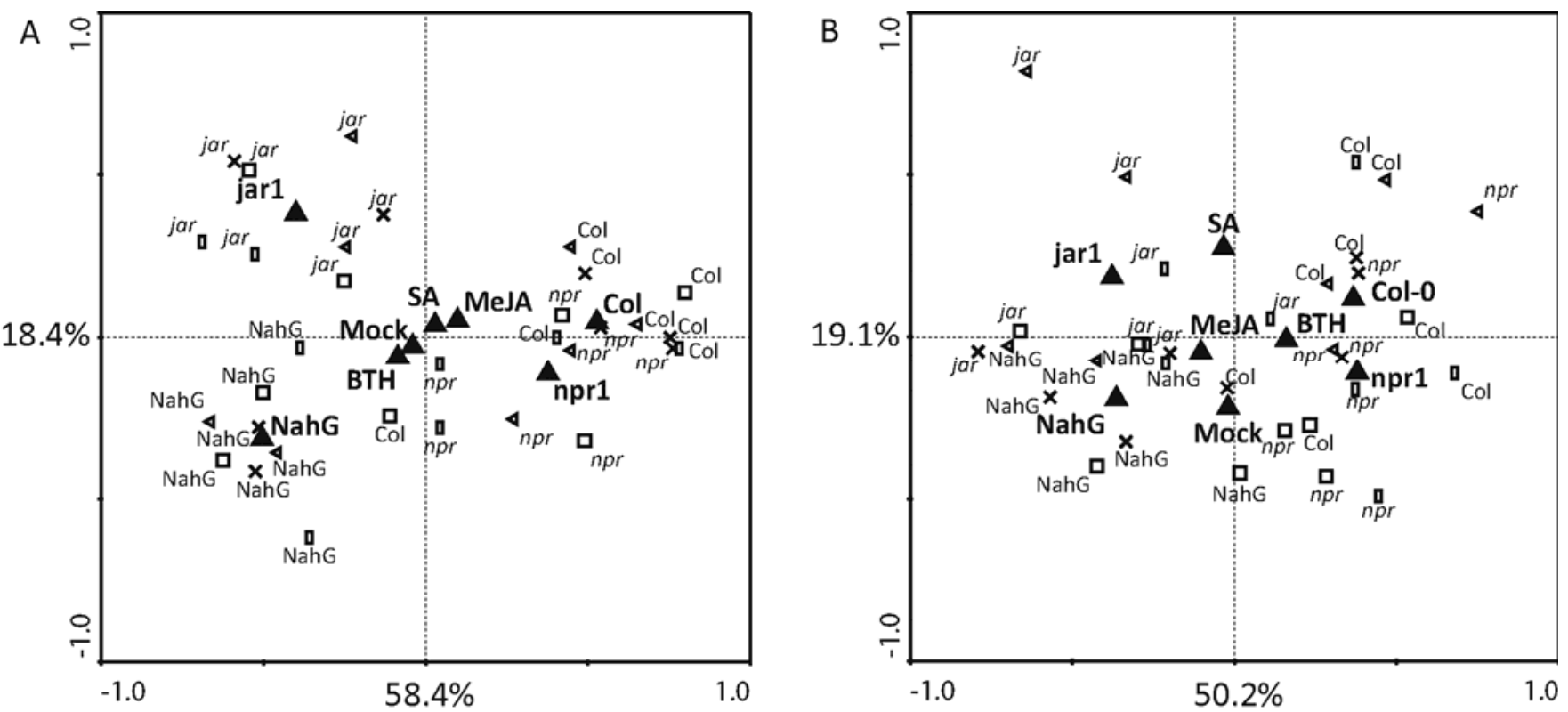

Fig. 9. Ordination biplots generated by redundancy analysis of A, eubacterial- and B, Pseudomonas spp.-specific fingerprints of the rhizosphere of the Arabidopsis genotypes Col-0 and its derivatives affected in defense signaling 2 weeks after foliar treatment with $0.1 \mathrm{mM}$ methyl-jasmonate (crosses), 1 mM salicylic acid (small triangles), or benzothiadiazole (200 $\mu$ g per milliliter) (rectangles), or mock treated (squares). Large triangles represent the centroid position of genotypes per treatment. 
on soils likely to contain opportunistic pathogens. Therefore, the observed differences in tobacco seem to be due to the increased sensitivity of the ET-insensitive Tetr18 plants to infection rather that to defective ET signaling per se. In contrast, differences observed in the rhizospheres of the different Arabidopsis genotypes do not appear to be related to plant defense. Therefore, control of plant diseases by activation of ISR or SAR is unlikely to have a significant impact on the indigenous soil microflora.

\section{MATERIALS AND METHODS}

\section{Cultivation of plants.}

Seeds of Arabidopsis thaliana wild type, accession Col- 0 , and the JA, ET, or SA signal-transduction mutants jar1-1, etrl-1, ein2-1, cprl-1, nprl-1, and NahG (Table 4) as well as seeds from Nicotiana tabacum cv. Samsun NN and its ET-insensitive transformant Tetr 18 were sown in autoclaved $\left(20 \mathrm{~min}\right.$ at $\left.121^{\circ} \mathrm{C}\right)$ sand. Seeds were kept at $4^{\circ} \mathrm{C}$ in the dark for 2 days and were subsequently allowed to germinate in a greenhouse with a cycle of an 8-h day $\left(200 \mu \mathrm{E} \mathrm{m}^{-2} \mathrm{~s}^{-1}\right)$ at $24^{\circ} \mathrm{C}$ and $16-\mathrm{h}$ night at $20^{\circ} \mathrm{C}$ and $70 \%$ relative humidity. After two weeks, germinated seedlings were transferred individually to $60-\mathrm{ml}$ pots containing either a potting soil-sand mixture (12:5 vol/vol) (Pieterse et al. 1996) or a clay soil (Glandorf et al. 2001; Viebahn et al. 2003). Both soils were either nonautoclaved or autoclaved (twice for 20 min at $121^{\circ} \mathrm{C}$ with a $24-\mathrm{h}$ interval). The transferred seedlings were grown under the conditions described above. Plants were watered with half-strength Hoagland nutrient solution (Hoagland and Arnon 1938) once a week and with tap water as required. All samples were harvested from 5-week-old plants. No differences were noticed between plants grown on autoclaved or nonautoclaved soils, but plants grew more slowly on the clay than on the potting soil-sand mixture.

\section{Foliar application of MeJA, SA, and BTH.}

Application of MeJA induces JA-dependent ISR (Pieterse et al. 1998), while application of SA or its functional analog BTH results in SAR (Gaffney et al. 1993; Lawton et al. 1996). One day before treatment, plants were put at $100 \%$ relative humidity. The leaves of 3-week-old plants were briefly submerged in an aqueous solution of either $0.1 \mathrm{mM}$ MeJA, $1 \mathrm{mM}$ SA, or BTH (200 $\mu \mathrm{g}$ per milliliter), were supplemented with 0.015\% Silwet L-77 (Van Meeuwen Chemicals BV, Weesp, The Netherlands), avoiding spillover to the soil. Leaves of control plants were briefly submerged in $0.015 \%$ Silwet L-77. After treatment, plants were further grown in the greenhouse as described above. After $24 \mathrm{~h}$, leaves and roots were harvested from some of the plants and were frozen in liquid nitrogen and stored at $-80^{\circ} \mathrm{C}$ for analysis of marker gene expression. Two weeks after chemical treatment, rhizosphere samples were harvested from the remaining plants for bacterial quantification and PCR-DGGE analysis.

\section{Quantification of bacteria.}

For five individual plants per treatment, roots with tightly adhering soil were harvested and were shaken three times in $10 \mathrm{mM} \mathrm{MgSO}{ }_{4}$ with glass beads $(0.6$ to $0.8 \mathrm{~mm}$ ) on a vortex at maximum speed for $1 \mathrm{~min}$. Population densities of aerobic heterotrophic bacteria were determined by plating serial dilutions on $1 / 10$ strength $\mathrm{TSA}^{+}$( $3 \mathrm{~g}$ of tryptic soy broth per liter [Difco Laboratories, Detroit], $13 \mathrm{~g}$ of agar technical per liter [Oxoid Ltd, Basingstoke, U.K.] and $100 \mathrm{mg}$ of natamycin per liter [Pedersen 1992] [Delvocid; DSM, Delft, The Netherlands] and counting CFU after 7 days of incubation at $20^{\circ} \mathrm{C}$. Quantification of Pseudomonas spp. was performed by plating appropriate dilutions on $\mathrm{KB}^{+}$(King's B agar [King et al. 1954] supplemented with $13 \mu \mathrm{g}$ of chloramphenicol per milliliter, 40 $\mu \mathrm{g}$ of ampicillin per milliliter, and $100 \mu \mathrm{g}$ of natamycin per milliliter [Delvocid; DSM] [Geels and Schippers 1983]) and counting CFU after incubation for $48 \mathrm{~h}$ at $28^{\circ} \mathrm{C}$.

\section{DNA extraction and PCR-analysis.}

Two replicate samples from five pooled individual plants each were analyzed for every treatment. DNA was extracted from the rhizosphere as described by Viebahn and associates (2005a). Briefly, $500 \mathrm{mg}$ of root material with adhering soil was used for direct DNA extraction with the FastDNA SPIN kit for soil (Bio101; Biogene, Vista, CA, U.S.A.), according to the manufacturer's instructions. Bead beating was performed with a Ribolyser (Hybaid, Ashford, U.K.), and for the final elution, $100 \mu \mathrm{l}$ of sterile water was used instead of $50 \mu \mathrm{l}$. DNA extracts were purified with the Wizard DNA clean-up system (Promega, Madison, WI, U.S.A.) according to the manufacturer's protocol. Amplification of the V6-V8 region of eubacterial 16S rDNA genes was done with primers 968f_GC and 1401R (Nübel et al. 1996). The PCR reaction mix consisted of $1 \times$ PCR buffer 2 (Roche Diagnostics, Mannheim, Germany), $250 \mu \mathrm{M}$ of each dNTP, 200 $\mathrm{nM}$ of each primer, $2.5 \mathrm{U}$ Expand Long Template enzyme (Roche Diagnostics), and $1 \mu$ l of purified DNA extract. PCR conditions used in the thermocycler (Hybaid, Ashford, U.K.) were $5 \mathrm{~min}$ at $94^{\circ} \mathrm{C}$, followed by 35 cycles of $1 \mathrm{~min}$ at $94^{\circ} \mathrm{C}, 1$ $\min$ at $66^{\circ} \mathrm{C}$, and $3 \mathrm{~min}$ at $72^{\circ} \mathrm{C}$, and a final extension of $10 \mathrm{~min}$ at $72^{\circ} \mathrm{C}$. PCR specific for Pseudomonas spp. was performed

Table 3. Two-way analysis of similarity of denaturing gradient-gel electrophoresis fingerprints of eubacteria and Pseudomonas spp. in the rhizospheres of Arabidopsis genotypes (Col-0, NahG, jar1, and nprl) that were treated with different hormones (salicylic acid, benzothiadiazole, methyl jasmonate)

\begin{tabular}{lccccc}
\hline & \multicolumn{3}{c}{ Eubacteria } & & \multicolumn{2}{c}{ Pseudomonas spp. } \\
\cline { 2 - 3 } \cline { 5 - 6 } Values & Genotype & Treatment & & Genotype & Treatment \\
\hline Global $R$ value & 0.41924 & -0.24219 & 0.30729 & -0.049479 \\
$P$ value & 0.0025 & 0.9757 & & 0.0188 & 0.6241 \\
\hline
\end{tabular}

Table 4. Listing and relevant characteristics of Arabidopsis lines used

\begin{tabular}{lll}
\hline Genotype & \multicolumn{1}{c}{ Relevant characteristics ${ }^{\mathbf{a}}$} & \multicolumn{1}{c}{ Reference } \\
\hline Col-0 & Wild-type accession Colombia-0 & Staswick et al. 1992 \\
jar1-1 & jasmonate resistance 1, JA-insensitive & Bleecker et al. 1988 \\
trl-1 & ethylene response 1, ET-insensitive & Guzman and Ecker 1990 \\
ein2-1 & ethylene insensitive 2, ET-insensitive & Cao et al. 1994; Pieterse and Van Loon 2004 \\
npr1-1 & nonexpressor of PR genes, impaired in SA- and JA/ET-dependent defense responses & Bowling et al. 1994 \\
cprl-1 & constitutive expressor of PR genes 1, SA overproducer & Delaney et al. 1994 \\
NahG & Transformant expressing bacterial SA hydroxylase, does not accumulate SA & \\
\hline
\end{tabular}

${ }^{\mathrm{a}} \mathrm{JA}=$ jasmonate, $\mathrm{ET}=$ ethylene, $\mathrm{PR}=$ pathogenesis related, and $\mathrm{SA}=$ salicylic acid. 
with 16S rDNA primers PsF and PsR (Widmer et al. 1998). To obtain Pseudomonas-specific amplicons suitable for separation by DGGE, nested PCR on 50-fold diluted primary PCR product was performed according to Garbeva and associates (2004b). All amplicons were checked for size and concentration by electrophoresis on a $1.0 \%$ agarose gel in $1 \times$ TAE (40 mM Tris-acetate, $20 \mathrm{mM}$ Na-acetate, and $1.0 \mathrm{mM}$ Na-EDTA, pH 8.0) (Sambrook et al. 1989).

\section{DGGE.}

PCR amplicons were separated on polyacrylamide gels with a 30 to $60 \%$ denaturant gradient ( $8 \%$ acrylamide, acrylamide/ bisacrylamide ratio $37.5: 1 ; 100 \%$ denaturing solution is $7 \mathrm{M}$ urea, $40 \%$ formamide). Depending on amplicon concentration, 15 to $25 \mu \mathrm{l}$ of PCR products were loaded in random order. Gels were run in $0.5 \times \mathrm{TAE}$ at $60^{\circ} \mathrm{C}$ for $17 \mathrm{~h}$ at $80 \mathrm{~V}$ in a DCode universal mutation detection system (Bio-Rad Laboratories, Veenendaal, The Netherlands). Gels were stained with 1:10,000 diluted CyberGold (Molecular Probes, Leiden, The Netherlands) in $0.5 \times$ TAE and were photographed on a bluelight transilluminator (Clare Chemical Research, Dolores, CO, U.S.A.) with a GeneGenius Bioimaging System (Syngene, Cambridge, U.K.).

\section{RNA extraction and quantitative PCR analysis.}

RNA extraction and quantitative PCR analysis were performed according to Van der Ent and associates (2008) and Czechowski and associates (2004). Briefly, frozen plant material of two replicates of two plants each was pulverized in a mortar with pestle. From a 500- $\mu$ l aliquot, total RNA was extracted by the addition of an equal volume of extraction buffer $(0.35 \mathrm{M}$ glycine, $0.0048 \mathrm{M} \mathrm{NaOH}, 0.34 \mathrm{M} \mathrm{NaCl}, 0.04 \mathrm{M}$ EDTA, 4\% (wt/vol) sodium dodecyl sulfate). The homogenates were extracted twice with an equal volume of phenol/chloroform/isoamylalcohol (25:24:1), followed by an extraction with an equal volume of chloroform/isoamylalcohol (24:1). RNA was precipitated with $\mathrm{LiCl}$ and was purified by $\mathrm{NaAc}(\mathrm{pH} 5.2)$ and ethanol precipitation, according to Sambrook and associates (1989). RNA $(2 \mu \mathrm{g})$ was DNAse treated (Ambion, Huntingdon, U.K.) according to the manufacturer's instructions. To check for contamination with genomic DNA, a PCR with primers for EIL2 (At5g21120) was carried out (EIL2fw: TCT CGT GAG ACG GTC TAG AAG TT; EIL2rev: ATG AAA CCT AAT CTT CTC CAT TGC), as described by Van der Ent and associates (2008).

DNA-free total RNA was converted to cDNA, using oligo dT20 primers (Invitrogen, Breda, The Netherlands), dNTPs, and SuperScript III reverse transcriptase (Invitrogen, Breda, The Netherlands), according to the manufacturer's instructions. Quantitative PCR reactions took place in optical 96-well plates with a MqIQ Single Color real-time PCR detection system (Bio-Rad), using Power SYBR Green PCR master mix (Applied Biosystems, Warrington, U.K.) according to the manufacturer's instructions, with primers designed for $P R-1$ (At2g14610: $P R$ - $1 \mathrm{fw}$, CTC GGA GCT ACG CAG AAC AA; $P R-l$ rev, TTC TCG CTA ACC CAC ATG TTC A) and VSP2 (At5g24770: VSP2fw, TCG AAG TTG ACG CAA GTG GT; VSP2rev, GGG GAC AAT GCC ATG AAG AT). Expression of $P R-1$ and $V S P 2$ was corrected for the constitutively expressed reference gene At 1 g13320 encoding protein phosphatase 2A subunit A3 (At1g13320fw: TAA CGT GGC CAA AAT GAT GC; At1g13320rev: GTT CTC CAC AAC CGC TTG GT), after which expression levels were calculated with respect to the control treatments.

\section{Statistics.}

Bacterial plate counts were ${ }^{10} \log$ transformed and were analyzed by analysis of variance and Tukey post-hoc test $(P<$
0.05) (SPSS v16.0). Power analysis was performed with PASS 2008 (NCSS, Kaysville, Utah, U.S.A.). To study effects of plant genotype and hormone treatments on the microbial community, we used redundancy analysis (Ramette 2007). The analysis was performed with Bionumerics v4.5 program (Applied Maths, Sint-Martens,-Latem, Belgium) and Canoco v4.5 (Microcomputer Power, Ithaca, NY, U.S.A.), as described previously (Costa et al. 2006). Briefly, images were aligned and standardized with Bionumerics v4.5 prior to generation of the presence or absence and relative peak intensities data of different band positions within each lane. Subsequently, Canoco v4.5 was used for ordination of DGGE fingerprints and environmental variables in the biplots. Detrending corresponding canonical analysis (DCCA) was applied to check for heterogeneity within the data set. Since DCCA analysis indicated a homogeneous data set, the use of RDA or principal component analysis was used as the most appropriate algorithm to generate the ordination plots. In the ordination plots, distances between symbols represent a measure of similarity in that symbols that lie close together have a similar community structure, whereas a large distance between symbols indicates differences in community structure. The $x$ axis corresponds to the first eigenvalue and explains a higher percentage of the total variance than the $y$ axis, which corresponds to the second component. Thus, the first component is more important for explaining the variance than the second (Marschner and Rumberger 2004). In case of RDA analysis, Monte Carlo permutation tests were performed to assess the significance of DGGE-derived fingerprints and environmental correlations, assuming that DGGE ribotype is not related to environment. One- or two-way analysis of similarity (ANOSIM) was subsequently performed to compare microbial community structures as affected by plant genotype, hormone treatments, or both. The distance measure used was Bray-Curtis. The significance was examined by a permutation test where $R$ was recomputed for 10,000 permutations. Results from pairwise ANOSIM were analyzed to interpret the main between-group differences: $R>0.75$ separated bacterial and Pseudomonas compositions, $R>0.5$ was considered as overlapping but clearly different, and $R<0.25$ as barely separating. Calculation of similarity coefficients and ANOSIM analysis were carried out using PAST (Hammer et al 2001).

All experiments were performed at least twice with comparable results.

\section{ACKNOWLEDGMENTS}

We thank K. Wernars and B. van Rotterdam (the National Institute of Public Health and the Environment, Bilthoven, The Netherlands) for their hospitality to perform DGGE analysis and I. van der Tweel (Utrecht University) for performing the Power analysis. T. Van and J. Vervoort are acknowledged for technical assistance.

\section{LITERATURE CITED}

Bakker, P. A. H. M., Pieterse, C. M. J., and Van Loon, L. C. 2007. Induced systemic resistance by fluorescent Pseudomonas spp. Phytopathology 97:239-243.

Berg, G., and Smalla, K. 2009. Plant species and soil type cooperatively shape the structure and function of microbial communities in the rhizosphere. FEMS (Fed. Eur. Microbiol. Soc.) Microbiol. Ecol. 68:113.

Bleecker, A. B., Estelle, M. A., Somerville, C., and Kende, H. 1988. Insensitivity to ethylene conferred by a dominant mutation in Arabidopsis thaliana. Science 241:1086-1089.

Bowling, S. A., Guo, A., Cao, H., Gordon, A. S., Klessig, D. F., and Dong, X. 1994. A mutation in Arabidopsis that leads to constitutive expression of systemic acquired resistance. Plant Cell 6:1845-1857.

Cao, H., Bowling, S. A., Gordon, A. S., and Dong, X. 1994. Characterization of an Arabidopsis mutant that is nonresponsive to inducers of systemic acquired resistance. Plant Cell 6:1583-1592. 
Conrath, U., Pieterse, C. M. J., and Mauch-Mani, B. 2002. Priming in plant-pathogen interactions. Trends Plant Sci. 7:210-216.

Conrath, U., Beckers, G. J. M., Flors, V., Garcia-Agustin, P., Jakab, G., Mauch, F., Newman, M. A., Pieterse, C. M. J., Poinssot, B., Pozo, M. J., Pugin, A., Schaffrath, U., Ton, J., Wendehenne, D., Zimmerli, L., and Mauch-Mani, B. 2006. Priming: Getting ready for battle. Mol. PlantMicrobe Interact. 19:1062-1071.

Costa, R., Salles, J. F., Berg, G., and Smalla, K. 2006. Cultivation-independent analysis of Pseudomonas species in soil and in the rhizosphere of field-grown Verticillium dahliae host plants. Environ. Microbiol. 8:2136-2149.

Czechowski, T., Bari, R. P., Stitt, M., Scheible, W. R., and Udvardi, M. K 2004. Real-time RT-PCR profiling of over 1400 Arabidopsis transcription factors: Unprecedented sensitivity reveals novel root- and shootspecific genes. Plant J. 38:366-379.

De Vleesschauwer, D., Djavaheri, M., Bakker, P. A. H. M., and Höfte, M 2008. Pseudomonas fluorescens WCS374r-induced systemic resistance in rice against Magnaporthe oryzae is based on pseudobactin-mediated priming for a salicylic acid-repressible multifaceted defense response. Plant Physiol. 148:1996-2012.

Delaney, T. P., Uknes, S., Vernooij, B., Friedrich, L., Weymann, K., Negrotto, D., Gaffney, T., Gut-Rella, M., Kessmann, H., Ward, E., and Ryals, J. 1994. A central role of salicylic acid in plant disease resistance. Science 266:1247-1250.

Doornbos, R. F. 2009. Analysis of rhizosphere bacterial communities in Arabidopsis: Impact of plant defense signaling. Ph.D. thesis, Utrecht University, The Netherlands.

Durrant, W. E., and Dong, X. 2004. Systemic acquired resistance. Annu. Rev. Phytopathol. 42:185-209.

Friedrich, L., Lawton, K., Ruess, W., Masner, P., Specker, N., Rella, M. G., Meier, B., Dincher, S., Staub, T., Uknes, S., Métraux, J. P., Kessmann, H., and Ryals, J. 1996. A benzothiadiazole derivative induces systemic acquired resistance in tobacco. Plant J. 10:61-70.

Gaffney, T., Friedrich, L., Vernooij, B., Negrotto, D., Nye, G., Uknes, S., Ward, E., Kessmann, H., and Ryals, J. 1993. Requirement of salicylic acid for the induction of systemic acquired resistance. Science 261:754-756.

Garbeva, P., Van Veen, J. A., and Van Elsas, J. D. 2004a. Microbial diversity in soil: Selection of microbial populations by plant and soil type and implications for disease suppressiveness. Annu. Rev. Phytopathol. 42:243-270.

Garbeva, P., Van Veen, J. A., and Van Elsas, J. D. 2004b. Assessment of the diversity, and antagonism towards Rhizoctonia solani AG3, of Pseudomonas species in soil from different agricultural regimes. FEMS (Fed. Eur. Microbiol. Soc.) Microbiol. Ecol. 47:51-64.

Geels, F. P., and Schippers, B. 1983. Selection of antagonistic fluorescent Pseudomonas spp. and their root colonization and persistence following treatment of seed potatoes. Phytopath. Z. 108:193-206.

Geraats, B. P. J. 2003. The role of ethylene perception in plant disease resistance. Page 127 Ph.D. thesis. Utrecht University, Utrecht, The Netherlands.

Geraats, B. P. J., Bakker, P. A. H. M., and Van Loon, L. C. 2002. Ethylene insensitivity impairs resistance to soilborne pathogens in tobacco and Arabidopsis thaliana. Mol. Plant-Microbe Interact. 15:1078-1085.

Geraats, B. P. J., Bakker, P. A. H. M., Lawrence, C. B., Achuo, E. A., Höfte, M., and Van Loon, L. C. 2003. Ethylene-insensitive tobacco shows differentially altered susceptibility to different pathogens. Phytopathology 93:813-821.

Glandorf, D. C. M., Verheggen, P., Jansen, T., Jorritsma, J. W., Smit, E., Leeflang, P., Wernars, K., Thomashow, L. S., Laureijs, E., ThomasOates, J. E., Bakker, P. A. H. M., and Van Loon, L. C. 2001. Effect of genetically modified Pseudomonas putida WCS358r on the fungal rhizosphere microflora of field-grown wheat. Appl. Environ. Microbiol. 67:3371-3378.

Glazebrook, J. 2005. Contrasting mechanisms of defense against biotrophic and necrotrophic pathogens. Annu. Rev. Phytopathol. 43:205-227.

Guzman, P., and Ecker, J. R. 1990. Exploiting the triple response of Arabidopsis to identify ethylene-related mutants. Plant Cell 2:513-523.

Hammer, O., Harper, D. A. T., and Ryan, P. D. 2001. PAST: Paleontological Statistics Software Package for Education and Data Analysis. Palaeontologia Electronica 4:1-9.

Heidel, A. J., Clarke, J. D., Antonovics, J., and Dong, X. 2004. Fitness costs of mutations affecting the systemic acquired resistance pathway in Arabidopsis thaliana. Genetics 168:2197-2206.

Hein, J. W., Wolfe, G. V., and Blee, K. A. 2008. Comparison of rhizosphere bacterial communities in Arabidopsis thaliana mutants for systemic acquired resistance. Microb. Ecol. 55:333-343.

Hien Dao, T. T., Puig, R. C., Kim, H. K., Erkelens, C., Lefeber, A. W. M., Linthorst, H. J. M., Choi, Y. H., and Verpoorte, R. 2009. Effect of benzothiadiazole on the metabolome of Arabidopsis thaliana. Plant Physiol. Biochem. 47:146-152.
Hoagland, D. R., and Arnon, D. I. 1938. The water culture method for growing plants without soil. Calif. Agric. Exp. Stn. Bull. 347:36-39.

Hukkanen, A. T., Kokko, H. I., Buchala, A. J., McDougall, G. J., Stewart, D., Karenlampi, S. O., and Karjalainen, R. O. 2007. Benzothiadiazole induces the accumulation of phenolics and improves resistance to powdery mildew in strawberries. J. Agric. Food Chem. 55:1862-1870.

King, E. O., Ward, M. K., and Raney, D. E. 1954. Two simple media for the demonstration of phycocyanin and fluorescin. J. Lab. Clin. Med. 44:301-307.

Knoester, M., Van Loon, L. C., Van den Heuvel, J., Hennig, J., Bol, J. F., and Linthorst, H. J. M. 1998. Ethylene-insensitive tobacco lacks nonhost resistance against soil-borne fungi. Proc. Natl. Acad. Sci. U.S.A. 95:1933-1937.

Lawton, K. A., Friedrich, L., Hunt, M., Weymann, K., Delaney, T., Kessmann, H., Staub, T., and Ryals, J. 1996. Benzothiadiazole induces disease resistance in Arabidopsis by activation of the systemic acquired resistance signal transduction pathway. Plant J. 10:71-82.

Loake, G., and Grant, M. 2007. Salicylic acid in plant defence-The players and protagonists. Curr. Opin. Plant Biol. 10:466-472.

Marschner, P., and Rumberger, A. 2004. Rapid changes in the rhizosphere bacterial community structure during re-colonization of sterilized soil. Biol. Fertil. Soils 40:1-6.

Marschner, P., Yang, C.-H., Lieberei, R., and Crowley, D. E. 2001. Soil and plant specific effects on bacterial community composition in the rhizosphere. Soil Biol. Biochem. 33:1437-1445.

Micallef, S. A., Shiaris, M. P., and Colón-Carmona, A. 2009. Influence of Arabidopsis thaliana accessions on rhizobacterial communities and natural variation in root exudates. J. Exp. Bot. 60:1729-1742.

Nübel, U., Engelen, B., Felske, A., Snaidr, J., Wieshuber, A., Amann, R. I., Ludwig, W., and Backhaus, H. 1996. Sequence heterogeneities of genes encoding 16S rRNAs in Paenibacillus polymyxa detected by temperature gradient gel electrophoresis. J. Bacteriol. 178:5636-5643.

Pedersen, J. C. 1992. Natamycin as a fungicide in agar media. Appl. Environ. Microbiol. 58:1064-1066.

Pieterse, C. M., and Van Loon, L. C. 2004. NPR1: The spider in the web of induced resistance signaling pathways. Curr. Opin. Plant Biol. 7:456464.

Pieterse, C. M. J., Van Wees, S. C. M., Hoffland, E., Van Pelt, J. A., and Van Loon, L. C. 1996. Systemic resistance in Arabidopsis induced by biocontrol bacteria is independent of salicylic acid accumulation and pathogenesis-related gene expression. Plant Cell 8:1225-1237.

Pieterse, C. M. J., Van Wees, S. C. M., Van Pelt, J. A., Knoester, M., Laan, R., Gerrits, N., Weisbeek, P. J., and Van Loon, L. C. 1998. A novel signaling pathway controlling induced systemic resistance in Arabidopsis. Plant Cell 10:1571-1580.

Pieterse, C. M. J., Van Pelt, J. A., Ton, J., Parchmann, S., Mueller, M. J., Buchala, A. J., Métraux, J.-P., and Van Loon, L. C. 2000. Rhizobacteriamediated induced systemic resistance (ISR) in Arabidopsis requires sensitivity to jasmonate and ethylene but is not accompanied by an increase in their production. Physiol. Mol. Plant Pathol. 57:123-134.

Ramette, A. 2007. Multivariate analyses in microbial ecology. FEMS (Fed Eur. Microbiol. Soc.) Microbiol. Ecol. 62:142-160.

Sambrook, J., Fritsch, E. F., and Maniatis, T. 1989. Molecular Cloning: A Laboratory Manual. Cold Spring Harbor Laboratory Press, Cold Spring Harbor, NY, U.S.A.

Staswick, P. E., Su, W. P., and Howell, S. H. 1992. Methyl jasmonate inhibition of root growth and induction of a leaf protein are decreased in an Arabidopsis-thaliana mutant. Proc. Natl. Acad. Sci. U.S.A. 89:6837 6840

Thomma, B. P. H. J., Eggermont, K., Penninckx, I. A. M. A., Mauch-Mani, B., Vogelsang, R., Cammue, B. P. A., and Broekaert, W. F. 1998. Separate jasmonate-dependent and salicylate-dependent defense-response pathways in Arabidopsis are essential for resistance to distinct microbial pathogens. Proc. Natl. Acad. Sci. U.S.A. 95:15107-15111.

Ton, J., Van Pelt, J. A., Van Loon, L. C., and Pieterse, C. M. J. 2002. Differential effectiveness of salicylate-dependent and jasmonate/ethylenedependent induced resistance in Arabidopsis. Mol. Plant-Microbe Interact. 15:27-34

Van der Ent, S., Verhagen, B. W. M., Van Doorn, R., Bakker, D., Verlaan, M. G., Pel, M. J. C., Joosten, R. G., Proveniers, M. C. G., Van Loon, L. C., Ton, J., and Pieterse, C. M. J. 2008. MYB72 is required in early signaling steps of rhizobacteria-induced systemic resistance in arabidopsis. Plant Physiol. 146:1293-1304.

Van Hulten, M., Pelser, M., Van Loon, L. C., Pieterse, C. M. J., and Ton, J. 2006. Costs and benefits of priming for defense in Arabidopsis. Proc. Natl. Acad. Sci. U.S.A. 103:5602-5607.

Van Loon, L. C. 2007. Plant responses to plant growth-promoting rhizobacteria. Eur. J. Plant Pathol. 119:243-254.

Van Loon, L. C., and Bakker, P. A. H. M. 2003. Signalling in rhizobacteria-plant interactions. Pages 287-330 in: Ecological Studies, Vol. 168 , 
Root Ecology. J. De Kroon and E. J. W. Visser, eds. Springer Verlag, Berlin.

Van Loon, L. C., Bakker, P. A. H. M., and Pieterse, C. M. J. 1998. Systemic resistance induced by rhizosphere bacteria. Annu. Rev. Phytopathol. 36:453-483.

Van Wees, S. C. M., and Glazebrook, J. 2003. Loss of non-host resistance of Arabidopsis NahG to Pseudomonas syringae pv. phaseolicola is due to degradation products of salicylic acid. Plant J. 33:733-742.

Van Wees, S. C. M., Van der Ent, S., and Pieterse, C. M. J. 2008. Plant immune responses triggered by beneficial microbes. Curr. Opin. Plant Biol. 11:443-448.

Van Wees, S. C. M., Luijendijk, M., Smoorenburg, I., Van Loon, L. C., and Pieterse, C. M. J. 1999. Rhizobacteria-mediated induced systemic resistance (ISR) in Arabidopsis is not associated with a direct effect on expression of known defense-related genes but stimulates the expression of the jasmonate-inducible gene Atvsp upon challenge. Plant Mol. Biol. 41:537-549.

Verhagen, B. W. M., Glazebrook, J., Zhu, T., Chang, H.-S., Van Loon, L. C., and Pieterse, C. M. J. 2004. The transcriptome of rhizobacteriainduced systemic resistance in Arabidopsis. Mol. Plant-Microbe Interact. 17:895-908.

Viebahn, M., Veenman, C., Wernars, K., Van Loon, L. C., Smit, E., and Bakker, P. A. H. M. 2005a. Assessment of differences in ascomycete communities in the rhizosphere of field-grown wheat and potato. FEMS (Fed. Eur. Microbiol. Soc.) Microbiol. Ecol. 53:245-253.

Viebahn, M., Glandorf, D. C. M., Ouwens, T. W. M., Smit, E., Leeflang, P., Wernars, K., Thomashow, L. S., Van Loon, L. C., and Bakker, P. A. H. M. 2003. Repeated introduction of genetically modified Pseudomo- nas putida WCS358r without intensified effects on the indigenous microflora of field-grown wheat. Appl. Environ. Microbiol. 69:31103118.

Walker, T. S., Bais, H. P., Halligan, K. M., Stermitz, F. R., and Vivanco, J. M. 2003b. Metabolic profiling of root exudates of Arabidopsis thaliana. J. Agric. Food Chem. 51:2548-2554.

Walters, D., and Heil, M. 2007. Costs and trade-offs associated with induced resistance. Physiol. Mol. Plant Pathol. 71:3-17.

Weller, D. M. 1988. Biological control of soilborne plant-pathogens in the rhizosphere with bacteria. Annu. Rev. Phytopathol. 26:379-407.

Whipps, J. M. 2001. Microbial interactions and biocontrol in the rhizosphere. J. Exp. Bot. 52:487-511.

Widmer, F., Seidler, R. J., Gillevet, P. M., Watrud, L. S., and Di Giovanni, G. D. 1998. A highly selective PCR protocol for detecting 16S rRNA genes of the genus Pseudomonas (sensu stricto) in environmental samples. Appl. Environ. Microbiol. 64:2545-2553.

Wilkinson, J. Q., Lanahan, M. B., Clark, D. G., Bleecker, A. B., Chang, C., Meyerowitz, E. M., and Klee, H. J. 1997. A dominant mutant receptor from Arabidopsis confers ethylene insensitivity in heterologous plants. Nature Biotechnol. 15:444-447.

Yen, K.-M., and Serdar, C. M. 1988. Genetics of naphthalene catabolism in Pseudomonads. Crit. Rev. Microbiol. 15:247-268.

Zehnder, G. W., Murphy, J. F., Sikora, E. J., and Kloepper, J. W. 2001. Application of rhizobacteria for induced resistance. Eur. J. Plant Pathol. 107:39-50.

Zhao, H., Chen, D., Li, Y., and Cai, B. 2005. Overexpression, purification and characterization of a new salicylate hydroxylase from naphthalenedegrading Pseudomonas sp strain ND6. Microbiol. Res. 160:307-313. 